\title{
Effects of an Interleukin-15 Antagonist on Systemic and Skeletal Alterations in Mice with DSS-Induced Colitis
}

\author{
Bénédicte Brounais-Le Royer, ${ }^{*}$ Dominique D. Pierroz, ${ }^{*}$ Dominique Velin, ${ }^{\dagger}$ Christophe Frossard, ${ }^{\ddagger}$ Xin Xiao Zheng, \\ Hans-Anton Lehr, "Sylvie Ferrari-Lacraz," and Serge L. Ferrari*
}

\begin{abstract}
From the Service of Bone Diseases, ${ }^{*}$ Department of Medical Specialties, the Inflammation and Allergy Research Group, ${ }^{\ddagger}$ Departments of Paediatrics and Internal Medicine, and the Transplantation Immunology Unit, ${ }^{\|}$Department of Genetic and Laboratory Medicine, Geneva University Hospital and Faculty of Medicine, Geneva, Switzerland; the Service of Gastroenterology and Hepatology ${ }^{\dagger}$ and the Institute of Pathology, ${ }^{\top}$ Centre Hospitalier Universitaire Vaudois and University of Lausanne, Lausanne, Switzerland; and the Transplantation Unit, ${ }^{\S}$ University of Pittsburgh, Pittsburgh
\end{abstract}

\author{
Accepted for publication \\ February 12, 2013. \\ Address correspondence to \\ Serge L. Ferrari, M.D., Service \\ of Bone Diseases, Department \\ of Medical Specialties, Geneva \\ University Hospital, 4, Rue \\ Gabrielle-Perret-Gentil, 1211 \\ Geneva 14, Switzerland. \\ E-mail: serge.ferrari@unige.ch.
}

\begin{abstract}
Inflammatory bowel diseases are commonly complicated by weight and bone loss. We hypothesized that IL-15, a pro-inflammatory cytokine expressed in colitis and an osteoclastogenic factor, could play a central role in systemic and skeletal complications of inflammatory bowel diseases. We evaluated the effects of an IL-15 antagonist, CRB-15, in mice with chronic colitis induced by oral $2 \%$ dextran sulfate sodium for 1 week, followed by another $1 \%$ for 2 weeks. During the last 2 weeks, mice were treated daily with CRB-15 or an IgG2a control antibody. Intestinal inflammation, disease severity, and bone parameters were evaluated at days 14 and 21. CRB-15 improved survival, early weight loss, and colitis clinical score, although colon damage and inflammation were prevented in only half the survivors. CRB-15 also delayed loss of femur bone mineral density and trabecular microarchitecture. Bone loss was characterized by decreased bone formation, but increased bone marrow osteoclast progenitors and osteoclast numbers on bone surfaces. CRB-15 prevented the suppression of osteoblastic markers of bone formation, and reduced osteoclast progenitors at day 14, but not later. However, by day 21, CRB-15 decreased tumor necrosis factor $\alpha$ and increased IL-10 expression in bone, paralleling a reduction of osteoclasts. These results delineate the role of IL-15 on the systemic and skeletal manifestations of chronic colitis and provide a proof-of-concept for future therapeutic developments. (Am J Pathol 2013, 182: 2155-2167; http://dx.doi.org/10.1016/j.ajpath.2013.02.033)
\end{abstract}

Although the etiology of inflammatory bowel diseases (IBDs), notably Crohn's disease and ulcerative colitis remain unclear, accumulating data suggest that altered innate and adaptive immune responses to enteric antigens play a pivotal role in intestinal inflammation. ${ }^{1}$ Patients with IBD also have low areal bone mineral density (BMD), deficits in trabecular volumetric bone mineral density, and an increased incidence of osteoporotic fractures, particularly at the spine and in women with Crohn's disease. ${ }^{2,3}$ The pathogenesis of osteoporosis in IBD involves both an increase in bone resorption and an inhibition of bone formation, resulting in a negative bone mineral balance. ${ }^{4}$ In addition to inflammation, these alterations in bone turnover are thought to be due to malnutrition, vitamin D and calcium deficiency, and corticosteroid treatment. ${ }^{5}$

Several mouse colitis models have been reported. ${ }^{6-8}$ Among them, dextran sulfate sodium (DSS) administration for 7 days is capable of inducing colitis even in severe combined immunodeficient mice, arguing for an early T-cell-independent mechanism of intestinal inflammation in this model. ${ }^{9}$ In contrast, T cells may play a more important role in worsening or perpetuating the disease when chronic colitis is induced by a prolonged period of DSS administration. ${ }^{10}$ In this case, bone mineral density and volume were reported to decrease in parallel to increased levels of tumor necrosis factor $\alpha(\mathrm{TNF} \alpha)$, and to recover on cessation of DSS administration and with colitis improvement. ${ }^{11}$

Several pro-inflammatory cytokines produced by activated $\mathrm{T}$ cells in IBD actually contribute to bone loss. They include $\mathrm{TNF} \alpha,{ }^{12-14} \mathrm{IL}-1 \beta,{ }^{15} \mathrm{IL}-6,{ }^{16,17}$ and interferon (IFN)- $\gamma,{ }^{18}$

Supported by a Crohn's and Colitis Foundation of America grant (S.L.F. and S.F.-L.), a Hans Wilsdorf Foundation grant (S.F.-L.), and Novartis Consumer Health Foundation, Novartis Foundation, and European Crohn's and Colitis Organisation fellowships (D.D.P. and B.B.-L.R.). 
which have been shown to enhance osteoclast differentiation and bone resorption and/or to inhibit osteoblast functions and bone formation. In addition, receptor activator of nuclear factor-kappa B ligand (RANKL) and its antagonist, osteoprotegerin (OPG), play a key role in the regulation of osteoclastogenesis and bone loss in inflammatory disorders, including IBD. ${ }^{19-21}$

IL-15, a major pro-inflammatory cytokine and T-cell growth factor ${ }^{22}$ is produced by epithelial and endothelial cells and monocytes/macrophages. ${ }^{23,24}$ High levels of IL-15 have been found in blood and inflamed mucosa of patients with $\mathrm{IBD}^{25,26} \mathrm{IL}-15$ regulates both innate and adaptive immune responses, is involved in the differentiation and proliferation of natural killer (NK) cells and T cells, and contributes to hematopoietic cell homeostasis. ${ }^{27}$ The trimeric receptor for IL-15 (IL-15R) is expressed on T cells, and it includes the constitutively expressed IL-2R $\beta$ and IL- $2 \mathrm{R} \gamma \mathrm{c}$ chains, and a unique IL-15R $\alpha$ chain only expressed on activated mononuclear cells. ${ }^{28}$ In IBD, increased levels of IL-15 in the inflamed intestine favor the expansion and activation of intraepithelial NK T cells and $\mathrm{CD}^{+} \mathrm{T}$ cells. ${ }^{29,30}$ Hence, IL-15 knockout $\left(I L-15^{-/}\right)$mice are less sensitive to both acute and chronic colitis after DSS administration. ${ }^{31}$ This attenuation of colitis severity in $I L-15^{-/}$mice is associated with a decrease of several T-cell subpopulations and of the production of TNF $\alpha$, IL-12, and IFN $\gamma$.

IL-15 not only induces proliferation and activation of $\mathrm{T}$ cells, but also directly acts on bone remodeling by stimulating pre-osteoclast differentiation. ${ }^{32}$ Indeed, osteoclasts express the high affinity IL- $15 \mathrm{R} \alpha$ chain and IL-15 influences osteoclastogenesis both directly, by co-stimulating RANKL-induced differentiation and activation processes in osteoclasts, and indirectly, by inducing proliferation and activation of $\mathrm{T}$ cells and their production of $\mathrm{IFN} \gamma$ and RANKL. ${ }^{33}$ In turn, IL-15R $\alpha$ deficient $\left(I L-15 R \alpha^{-1-}\right)$ mice present a high bone mass phenotype and improved bone microarchitecture in both the cancellous and cortical bone compartments. ${ }^{33}$

The potential therapeutic effect of an IL-15 mutant/Fc2a fusion protein (CRB-15) antagonist of IL-15R has been reported in several immune and inflammatory disorders. On the one hand, CRB-15 improves allograft survival due in part to the inhibition of activation and proliferation of $\mathrm{CD} 8^{+}$ alloreactive T cells. ${ }^{34}$ On the other hand, CRB-15 prevents the development of arthritis and blocks disease progression in a mouse model of collagen-induced arthritis. This effect is mainly associated with a decrease in synovitis in the joints and lymphocytic infiltration and reduced in situ production of pro-inflammatory cytokines, TNF $\alpha$, IL- $1 \beta$, IL- 6 , and IL-17. ${ }^{35,36}$

Accordingly, we hypothesized that IL-15 could play a central role in the systemic and skeletal complications of IBD. For this purpose, we studied the effects of CRB-15 in a mouse model of DSS-induced chronic colitis. We show herein that inhibition of IL-15 has distinct effects on bone formation and osteoclasts, and at least transiently improves bone loss, colitis clinical manifestations, and survival in mice exposed to DSS for 3 weeks.

\section{Materials and Methods}

\section{Experimental Procedures}

Female C57BL/6 mice, obtained from the animal core of our institution (Centre Médical Universitaire, Faculty of Medicine, Geneva) were used for this study. All mice were kept under conventional housing conditions with free access to a standard diet (RM3; Special Diets Services, Essex, UK).

Chronic colitis was induced in 10-week-old female mice by adding $2 \%$ of DSS (TdB Consultancy AB, Uppsala, Sweden) to the drinking water for 1 week, followed by $1 \%$ DSS for 2 weeks. Mice were treated daily with an antagonist of IL-15, CRB-15 $(5 \mu \mathrm{g} / 100 \mu \mathrm{L}$ per mouse i.p., as previously described ${ }^{35}$ ) from day 7 to day 21 after DSS administration to evaluate the effects of CRB-15 in established disease (ie, during the chronic phase of the colitis after reduction of DSS administration). As CRB-15 is a recombinant fusion protein consisting of a point-mutated IL-15 and the constant region of murine $\operatorname{IgG} 2 \mathrm{a},{ }^{35,37}$ an intact $\operatorname{IgG} 2 \mathrm{a}(5 \mu \mathrm{g} / 100 \mu \mathrm{L}$ per mouse, i.p.) was used as a control to confirm that the modulatory effect observed with CRB-15 was not due to the immunoglobulin part of the molecule but to the antagonist of IL-15. The experiment was repeated three times with similar results, totaling 7 to 27 mice per group. Water intake was monitored twice a week in each cage and related to the consumed quantity per mouse and per day. To assess the severity of colitis, mice were weighed and followed for the presence of rectal bleeding (Colo-rectal test; Axon Lab AG, Baden, Switzerland) three times per week. Femoral BMD $\left(\mathrm{mg} / \mathrm{cm}^{2}\right)$ was determined at baseline, 7 days, 14 days, and 21 days after DSS administration. Mice were euthanized by injection with $120 \mathrm{mg} / \mathrm{kg}$ ketamine $/ 16 \mathrm{mg} / \mathrm{kg}$ xylazine, and cervical dislocation 7 days (only for isolation of intraepithelial lymphocytes), 14 days, or 21 days after DSS administration. The fifth lumbar vertebra and femurs were collected for skeletal analyses, colons were removed for histological evaluation, RNA isolation, and myeloperoxidase activity determination, and spleen, lymph nodes, and bone marrow were collected for immunological analyses. The mice that died during the experiment were also evaluated for bone parameters and integrated in the different groups for analyses according to their time of death. All of the animal procedures were approved by the ethical committee of University of Geneva and the state of Geneva Veterinarian Office.

A disease activity index (DAI) score based on body weight loss and detection of fecal blood was determined. For each parameter, a score of 0 to 4 was attributed, giving rise to a maximal DAI score of 8 . The score was evaluated as follows: weight loss scores were: $0=$ no loss; $1=5 \%$ to $10 \% ; 2=10 \%$ to $15 \% ; 3=15 \%$ to $20 \%$; and $4=>20 \%$. Fecal blood scores were: $0=$ negative colorectal test; $2=$ positive colorectal test; $4=$ macroscopic blood in stools. 


\section{Bone Mineral Density and Microarchitecture}

Femoral BMD $\left(\mathrm{mg} / \mathrm{cm}^{2}\right)$ was measured in vivo using dual energy X-ray absorptiometry (pDXA, PIXImus; GE-Lunar Corporation, Madison, WI). Quantitative microcomputed tomography ( $\mu \mathrm{CT}$, UCT40; Scanco Medical AG, Basserdorf, Switzerland) was used as previously described. ${ }^{38}$ Specifically, the trabecular bone volume fraction (percentage), trabecular thickness $(\mu \mathrm{m})$, trabecular number $\left(\mathrm{mm}^{-1}\right)$, and trabecular separation $(\mu \mathrm{m})$ were evaluated at the fifth lumbar vertebra and distal femoral metaphysis, whereas for the cortical bone, the average total volume $\left(\mathrm{mm}^{3}\right)$, bone volume $\left(\mathrm{mm}^{3}\right)$, and cortical thickness $(\mu \mathrm{m})$ were evaluated at the femoral midshaft.

\section{Histomorphometry}

To measure dynamic indices of bone formation, mice received $20 \mathrm{mg} / \mathrm{kg}$ subcutaneous injections of calcein (Sigma-Aldrich, Buchs, Switzerland) at 9 and 2 days before euthanasia. Femurs were dehydrated in graded ethanol and embedded in methyl methacrylate (Merck, Darmstadt, Germany). Transversal sections ( $8 \mu \mathrm{m}$ thick) of the midshaft and sagittal sections $(5 \mu \mathrm{m}$ thick) were cut with a Leica Polycut E microtome (Leica Corporation Microsystems AG, Glattbrug, Switzerland) and mounted unstained for evaluation of fluorescence. Histomorphometric measurements were performed on the secondary spongiosa of the distal femoral metaphysis and on the endocortical and periosteal bone surfaces in the middle of the femur by using a $\mathrm{Q}$ image analyzer (Leica Corporation) at $\times 40$ magnification. All parameters were calculated and expressed according to standard formulas and nomenclatures ${ }^{39}$ : mineral apposition rate $(\mu \mathrm{m} /$ day), single-labeled surface per bone surface (percentage), and double-labeled surface per bone surface (percentage). Mineralizing surface per bone surface (percentage) was calculated by adding double-labeled surface per bone surface and one-half single-labeled surface per bone surface. Bone formation rate $\left(\mu \mathrm{m}^{3} / \mu \mathrm{m}^{2} /\right.$ day $)$ was calculated as the product of mineralizing surface per bone surface and mineral apposition rate. Only mineral apposition rate and bone formation rate obtained on the endocortical bone surfaces were presented in the Results. Sagittal sections ( $5 \mu \mathrm{m}$ thick) are stained with modified Goldner's trichrome to evaluate resorption parameters on the secondary spongiosa of the distal femoral metaphysis: number of osteoclasts per bone area, percentage of bone surface occupied by osteoclasts, and number of osteoclasts per bone perimeter. Only the number of osteoclasts per bone area is presented in the Results.

\section{Serum Biochemistry, Bone Turnover, and Cytokine Determination}

At baseline, 7 days, 14 days, and 21 days after DSS administration, mice were kept fasting for 6 hours and blood was collected by retro-orbital bleeding for biochemical evaluation. Sera were tested by ELISA to evaluate
C-terminal telopeptides of type I collagen (CTX, RatLaps EIA; Immunodiagnostic Systems, Frankfurt, Germany), by RIA to measure osteocalcin (Tecomedical, Sissach, Switzerland) and by a mouse cytokine 20-plex antibody bead kit (Invitrogen, Basel, Switzerland) for the determination of inflammatory cytokines levels. Data were analyzed on a Bio-Plex 200 System (Bio-Rad, Luminex xMAP Technology, Reinach, Switzerland).

\section{RNA Isolation from Bone and Real-Time PCR}

The whole femurs were excised, both femoral extremities were removed, and the shaft was flushed with cold phosphatebuffered saline to remove the bone marrow. Femoral diaphysis and extremities were immediately pulverized into a fine powder and homogenized in peqGold Trifast (PEQLAB Biotechnologie GmbH, Erlangen, Germany) using a FastPrep system apparatus (QBiogene, Illkirch, France) to achieve quantitative RNA extraction. Total RNA was extracted and then purified on miniature columns (RNeasy minikit; Qiagen, Basel, Switzerland). Single-stranded cDNA templates for quantitative real-time PCR analyses were performed using SuperScript III Reverse Transcriptase (Invitrogen) following the manufacturer's instructions. Quantitative real-time PCR was performed using predesigned TaqMan gene expression assays (Table 1) consisting of two unlabeled primers and a FAM dye-labeled TaqMan MGB probe and the correspondent buffer TaqMan universal PCR master mix (Applied Biosystems, Rotkreuz, Switzerland). A Biomek 2000 robot (Beckman Coulter, Nyon, Switzerland) was used for liquid handling in 384-well plates with three replicates per sample. The cDNA was PCR-amplified in a 7900HT SDS System, and raw threshold cycle $(C t)$ values were obtained from SDS software version 2.0 (Applied Biosystems). For each gene, the highest quantity was arbitrarily designated a value of 1.0. The mean quantity was calculated from triplicates for each sample, and this quantity was normalized to the similarly measured

Table 1 Taqman Gene Expression Assays and Primers for SYBR Green PCR

\begin{tabular}{|c|c|}
\hline Gene & TaqMan gene expression assays reference \\
\hline$I L-6$ & Mm00446190 \\
\hline$I L-10$ & Mm00439616 \\
\hline$T N F \alpha$ & Mm99999068 \\
\hline$O P G$ & Mm00435452 \\
\hline RANKL & Mm00441908 \\
\hline$A L P$ & Mm00475834 \\
\hline Col1A1 & Mm00801666 \\
\hline Gene & Primers for SYBR Green qPCR \\
\hline GAPDH & $\begin{array}{l}\text { Sense: } 5^{\prime}-\text { GCTAAGCAGTTGGTGGTGCA-3' } \\
\text { Antisense: 5'-TCACCACCATGGAGAAGGC-3' }\end{array}$ \\
\hline$I L-1 \beta$ & $\begin{array}{l}\text { Sense: 5'-CAACCAACAAGTGATATTCTCCATG-3' } \\
\text { Antisense: 5'-GATCCACACTCTCCAGCTGCA-3' }\end{array}$ \\
\hline IL-6 & 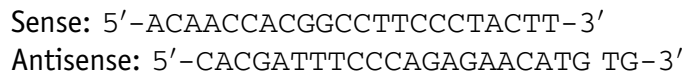 \\
\hline
\end{tabular}


mean quantity of the glyceraldehyde-3-phosphate dehydrogenase normalization gene. mRNAs obtained from different times of sacrifice were analyzed separately.

\section{Colon Histology and Immunohistochemistry}

At sacrifice, a segment of distal colon was excised and fixed in $10 \%$ buffered formalin. Paraffin sections were stained with $\mathrm{H} \& \mathrm{E}$ according to standard protocols. Histological scoring was performed by a pathologist as previously described..$^{40}$ Briefly, score consists of an inflammatory component $(0=$ rare inflammatory cells in the lamina propria; $1=$ increased numbers of inflammatory cells in the lamina propria; $2=$ confluence of inflammatory cells; extending into the submucosa; and $3=$ transmural extension of the infiltrate) and a tissue damage component $(0=$ no mucosal damage; $1=$ discrete lymphoepithelial lesions; 2 = surface mucosal erosion; $3=$ extensive mucosal damage and extension through deeper structures of the bowel wall). The combined histological score ranged from 0 (no changes) to 6 (extensive cell infiltration and tissue damage). For immunohistochemistry, the sections were deparaffinized in xylene, rehydrated in a descending series of ethanol. Deparaffinized slides were pretreated in 3\% hydrogen peroxide in methanol and rinsed in tap water, followed by nonspecific avidin/biotin blocking (avidin/biotin Blocking Kit; Reactolab S.A., Servion, Switzerland) according to the manufacturer's instructions. The slides were incubated with the primary antibody, the biotin anti-mouse $\gamma \delta$ T-cell receptor GL3 (BD Pharmingen, Basel, Switzerland) for 2 hours at $37^{\circ} \mathrm{C}$ and then with the fluorescein isothiocyanate-conjugated avidin reagent (BD Pharmingen) for 30 minutes at room temperature. Finally, the slides were washed and dehydrated for mounting. Immunohistology staining was analyzed using Axioskop 2 Plus and AxioVision Release software version 4.8 from Zeiss (Göttingen, Germany).

\section{MPO Activity}

Total proteins were extracted from colon samples using $0.5 \%$ Cetavlon, $10 \mathrm{mmol} / \mathrm{mL}$ morpholine-3-propanesulfonic acid (MPS, pH 7), extraction buffer, and were quantified using bicinchoninic acid protein assay (Bio-Rad, Reinach, Switzerland). Myeloperoxidase (MPO) activity was determined on $10 \mu \mathrm{g}$ of colon proteins by spectrophotometry $(405 \mathrm{~nm} / 550 \mathrm{~nm})$ as previously described. ${ }^{41}$

\section{RNA Isolation from Colon and Real-Time PCR}

RNA extraction was performed on a piece of colon using the Rneasy Mini kit (Qiagen). Single-stranded cDNA templates for quantitative real-time PCR analyses were performed using ThermoSript RT-PCR System (Invitrogen) following the manufacturer's instructions. Then PCR reaction was performed in duplicate on a MyiQ iCycler (Bio-Rad, Hercules, CA) using 96-well microtiter plates (Bio-Rad, Basel, Switzerland). The primers used in this experiment were described in Table 1. Quantification of input cDNA was performed using a standard curve as previously described. ${ }^{42}$

\section{Immune Cell Isolation and Analysis}

Peripheral lymph node and spleen cells from mice were harvested, and cell suspensions were prepared in Dulbecco's modified Eagle's medium supplemented with $10 \%$ heatinactivated fetal calf serum. $\mathrm{T}$ cells were enriched using Dynal Mouse T Cell Negative Isolation Kit (Invitrogen) and processed for analysis.

To collect bone marrow cells, femurs were excised, and both femoral extremities were cut to remove the bone marrow from the diaphysis by flushing with cold phosphatebuffered saline.

At sacrifice, the colon was excised to isolate intraepithelial lymphocytes (IELs) but the number of isolated cells was not enough to perform subpopulations analysis. Consequently, the small intestine was excised and IELs were isolated using modified methods as previously described. ${ }^{43}$ Briefly, fat tissue was removed, Peyer's patches were mechanically excised and the gut was extensively flushed with Hank's Buffered Salt Solution (Sigma-Aldrich). Intestinal pieces were longitudinally opened and cut into 5-mm pieces. Tissue pieces were incubated in calcium- and magnesium-free Hank's Buffered Salt Solution (Sigma-Aldrich) containing $2 \mathrm{mmol} / \mathrm{L}$ EDTA and $1 \mathrm{mmol} / \mathrm{L}$ dithiotreitol (Sigma-Aldrich) for 60 minutes at $37^{\circ} \mathrm{C}$ with magnetic stirring before being vigorously vortexed and filtered through $250-\mu \mathrm{m}$ nylon gauze. Intestinal IELs were obtained by a second filtration procedure through a nylon wool column. Cell population was washed twice and lymphocytes were enriched by discontinuous 15/30/44\% Percoll (Bioscience, Uppsala, Sweden) on a Lympholyte $M$ gradient (Cedarlane, Hornby, ON, Canada) for 20 minutes at $600 \mathrm{~g}$ at room temperature. Lymphocytes were harvested from the Percoll 44\% Lympholyte M interface.

The following rabbit anti-mouse monoclonal antibodies fluorochrome-conjugated and isotype-matched control monoclonal antibodies: CD3, CD4, CD8, CD $8 \alpha \alpha, \mathrm{CD} 8 \alpha \beta$, TCR $\alpha \beta, \mathrm{TCR} \gamma \delta$, CD11b, CD44, NK1.1 CD117, and CD115 were purchased from BD Pharmingen or eBioscience (Vienna, Austria). Three-to-five color immunofluorescence was performed to assess surface marker expression on T cells isolated from treated mice. Cells were washed twice with PBS (completed with $2 \%$ serum and $1 \% \mathrm{NaN}_{3}$ ) and treated successively with fluorochrome-conjugated monoclonal antibodies on ice for 30 minutes and washed with completed PBS. Cell staining was analyzed using a flow cytometer (FACSCalibur or FACSAria, BD Biosciences, Basel, Switzerland) and Cell Quest Pro software version 5.2.1 or FACS DIVA 6 software (BD Pharmingen). Gating CD $3^{+}$ cells was performed to analyze T-lymphocyte subpopulations and $\mathrm{CD} 8 \beta^{+}$cells were excluded to analyze the $\mathrm{CD} 8 \alpha \alpha^{+}$ subpopulation. To study osteoclastogenic population in bone marrow, ${ }^{44}$ analysis of CD115 and/or CD117 expression was done on CD3-CD45-CD11b- BM cell population. 


\section{Statistical Analysis}

Data were analyzed using a one-factor or two-factor analysis of variance to assess the effects of DSS administration and CRB-15 treatment. As appropriate, post hoc testing was performed using Fisher's Protected Least Significant
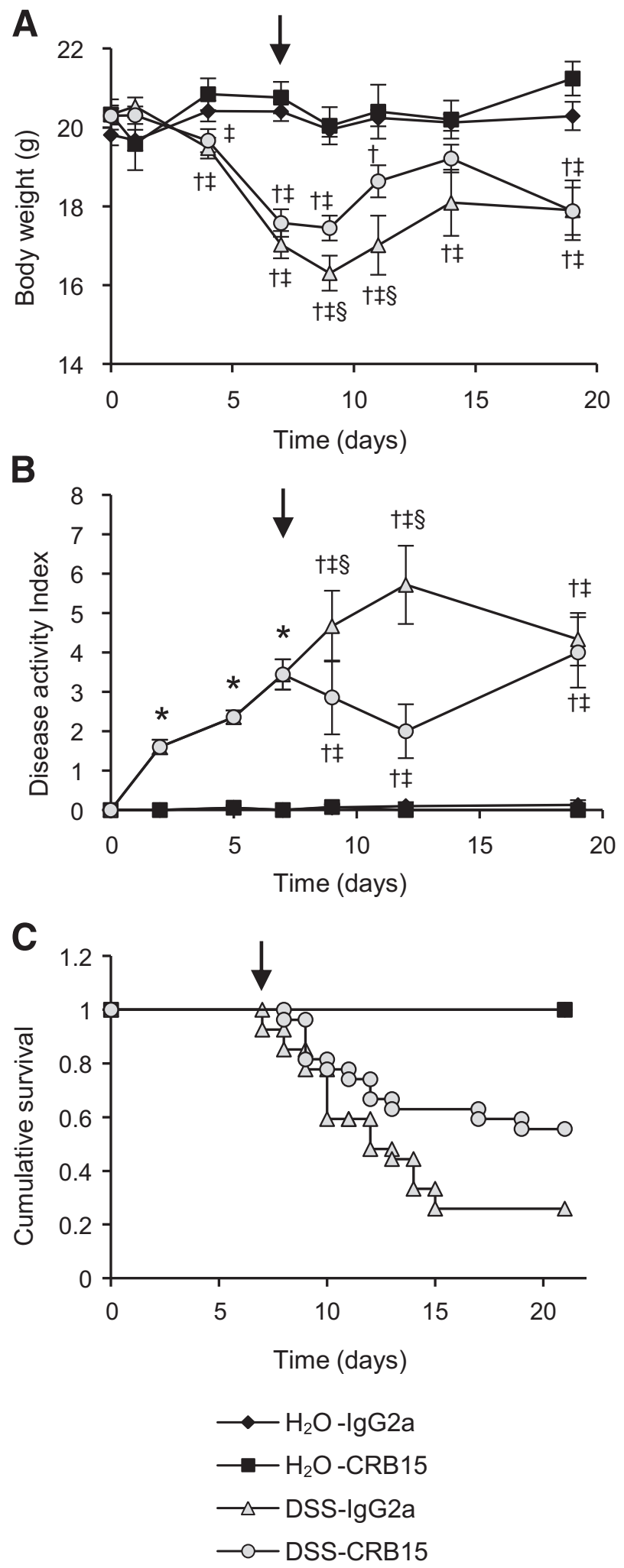

Difference (PLSD). The Kaplan-Meier method was used to analyze survival, and the differences between each individual curve with each other were calculated using a log-rank test. Differences were considered significant at $P \leq 0.05$. Data are presented as means \pm SEM unless otherwise noted.

\section{Results}

Improved Survival and Disease Activity Index by CRB-15

In the absence of other treatments, administration of $2 \%$ DSS for 1 week followed by $1 \%$ DSS for the next 2 weeks induced a severe colitis (as evaluated by body weight loss and bloody stools) starting from day 3. Hence mice exposed to DSS experienced $15 \%$ weight loss during the first week compared to their initial body weight (Figure 1A). In parallel, based on body weight loss and the presence of fecal blood, DSS rapidly increased the DAI from days 2 to 7 (Figure 1B). After DSS dose reduction to $1 \%$ and the beginning of treatments, weight loss continued at the same rate in mice receiving the $\operatorname{IgG} 2 \mathrm{a}$ control antibody, but was attenuated in those receiving CRB15 (-7.7\% in DSS-CRB-15 versus $-14.6 \%$ in DSS-IgG2a at day 11 compared to baseline). Importantly, water (containing DSS) intake was similar in IgG2a and CRB-15 groups (data not shown) indicating that weight differences between groups could not be explained by different DSS intakes. After 3 weeks, body weight had partially recovered in DSS-exposed mice and was no more different between IgG2a and CRB-15 treatment groups, although it remained significantly lower than controls $\left(\mathrm{H}_{2} \mathrm{O}\right)$ (Figure 1A). After the beginning of treatments, the DAI continued to rise until 14 days in DSSexposed mice treated with IgG2a, but then stabilized as the most severely affected mice died. In contrast, CRB-15 rapidly and significantly decreased DAI during the first week of treatment (Figure 1B). Consequently, CRB-15 significantly improved the survival rate in mice exposed to DSS at 14 and 21 days (63.0\% in DSS-CRB-15 versus 33.3\% in DSS-IgG2a; $P<0.05$ at 14 days; and $55.6 \%$ in DSS-CRB-15 versus $25.9 \%$ in DSS-IgG2a; $P<0.05$ at 21 days) (Figure $1 \mathrm{C}$ ).

\section{Effects of CRB-15 on Colonic and Systemic Inflammation}

Next we examined whether the effects of CRB-15 on morbidity and mortality were related to an improvement of

Figure 1 Body weight, disease activity index, and survival rate in IgG2aand CRB15-treated mice. Mice received 2\% DSS in drinking water for 1 week followed by $1 \%$ DSS for 2 weeks. I.P. treatment with $5 \mu \mathrm{g} / 100 \mu \mathrm{L}$ per mouse CRB-15 or IgG2a began after 7 days of DSS administration. Four groups of mice were analyzed: $\mathrm{H}_{2} \mathrm{O}-\mathrm{IgG} 2 \mathrm{a}, \mathrm{H}_{2} \mathrm{O}$-CRB15, DSS-IgG2a, and DSS-CRB15. A: Body weight was measured three times per week. B: Disease activity index was based on body weight and hemocultures. C: Survival rates of mice were monitored every day. Values are the means \pm SEM of three independent experiments $(n=$ 7 to 27 mice per group). Arrows indicate the beginning of treatment. ${ }^{*} P<$ 0.05 versus $\mathrm{H}_{2} 0,{ }^{\dagger} P<0.05$ versus $\mathrm{H}_{2} 0$-IgG2a, ${ }^{\ddagger} P<0.05$ versus $\mathrm{H}_{2} 0$-CRB-15, and ${ }^{\S} P<0.05$ versus DSS-CRB-15. 
A

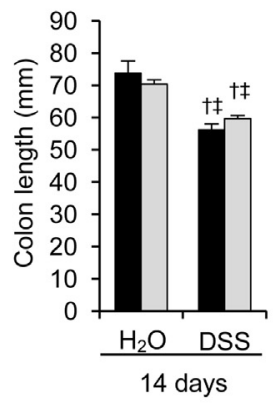

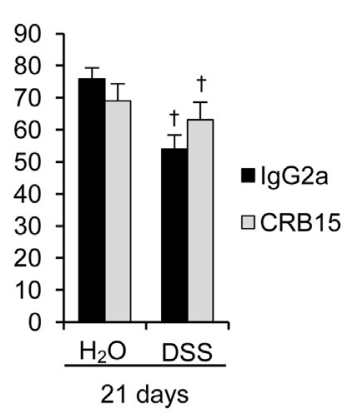

D

C

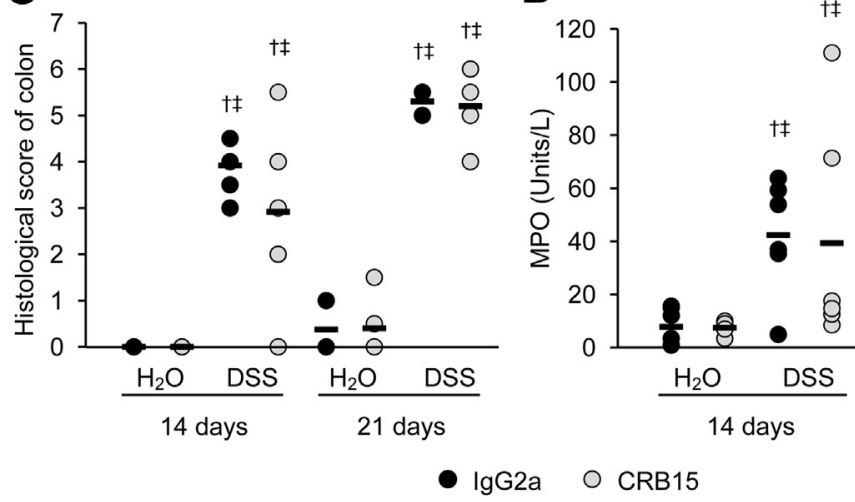

$\mathbf{F}$

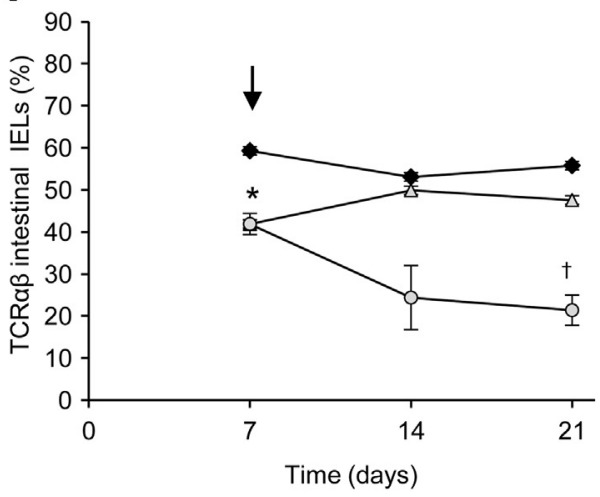

B

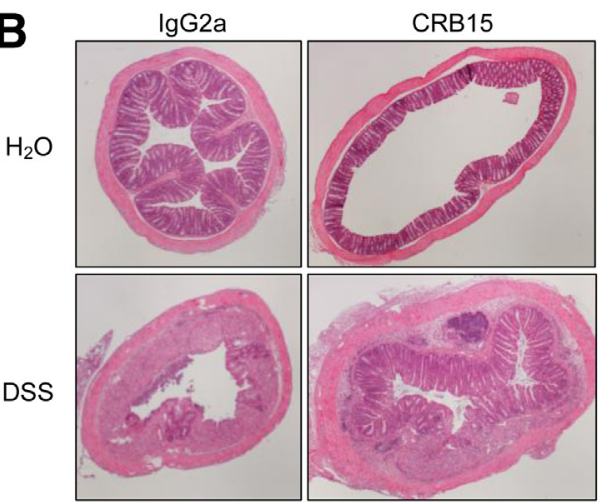

E

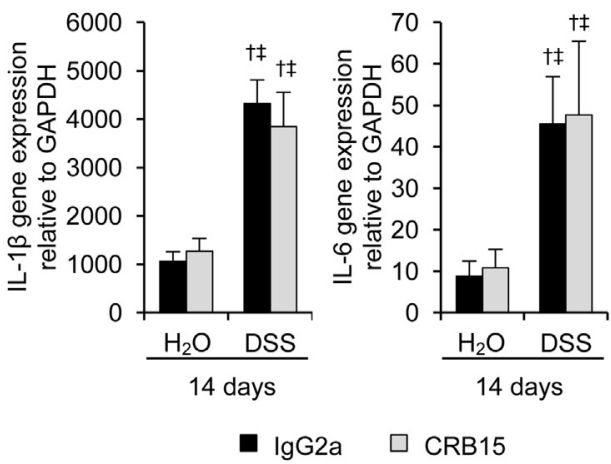

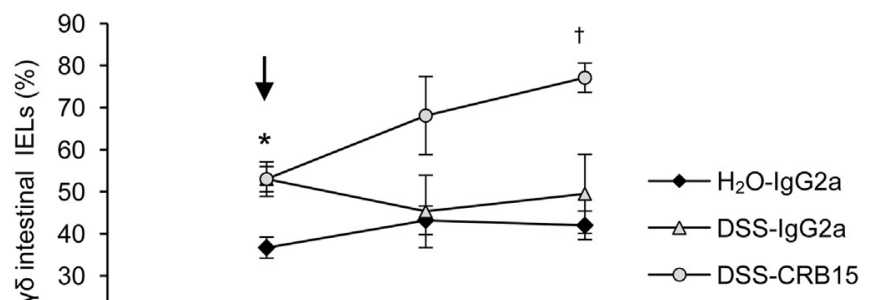

Figure 2 Analysis of intestinal inflammation in IgG2a- and CRB15-treated mice. A: Colon length was measured at time of sacrifice. Values are the means \pm SEM of two independent experiments ( $n=5$ to 16 mice per group). B: Representative images of colon stained with H\&E were obtained after 21 days of DSS (original magnification, $\times 40$ ). C: Histological scores of colon, based on inflammation and mucosal damage, were evaluated 14 days and 21 days after DSS administration. Each value was represented by a black dot and mean by a black line ( $n=4$ to 8 mice per group). D: MPO activity was measured 14 days after DSS administration. Each value was represented by a black dot and mean by a black line ( $n=6$ mice per group). E: Expression of mRNA for Il $1 \beta$ and Il 6 genes was determined as a ratio of mRNA to the housekeeping gene glyceraldehyde-3-phosphate dehydrogenase. mRNA expression was analyzed 14 days after DSS administration. Values are the means \pm SEM ( $n=6$ mice per group). F: The percentage of TCR $\alpha \beta^{+}$and TCR $\gamma \delta^{+}$among $\mathrm{CD}^{+}$cells of intestinal epithelium was analyzed by flow cytometry 7 days, 14 days, and 21 days after DSS administration. Values are means \pm SEM of three experiments with a pool of two mice per group. Arrows indicate the beginning of treatment. ${ }^{*} P<0.05$ versus $\mathrm{H}_{2} 0,{ }^{\dagger} P<0.05$ versus $\mathrm{H}_{2} 0$-IgG2a, and ${ }^{\ddagger} P<0.05$ versus $\mathrm{H}_{2} 0$-CRB- 15 .

inflammatory parameters both in the colon and systemically. The colon was significantly shortened by DSS administration at days 14 and 21, consistent with the presence of colitis (Figure 2A). Moreover, histological analysis indicated a massive destruction of the colonic epithelium associated with a transmural infiltration of inflammatory cells in DSSIgG2a-treated mice compared to controls $\left(\mathrm{H}_{2} \mathrm{O}\right)$ (Figure 2B) and an elevated histological score of colon based on infiltration of inflammatory cells and mucosal damage at days
14 and 21 (Figure 2C). Average levels of MPO activity, a marker of inflammatory response directly related to neutrophil infiltration, were also elevated in mice exposed to DSS (Figure 2D). Eventually, gene expression level of two pro-inflammatory cytokines, IL- $1 \beta$ and IL-6, were increased after 14 days and 21 days of DSS administration in the colon (Figure 2E). After 2 weeks of treatments, colon length did not significantly differ between IgG2a and CRB-15 groups, which could be explained by a survival bias 
(ie, a less severe degree of colitis among the fewer survivors in the $\mathrm{IgG} 2 \mathrm{a}$ group) (Figure 2A). However, in some but not all DSS-CRB-15-treated mice, colonic epithelium was partially preserved despite the presence of edema and inflammatory infiltrates (Figure 2B). The heterogeneity of the colonic response to CRB-15 was further illustrated by the histological score of colon, which on average was elevated in both treatment groups (CRB-15 and IgG2a) but remained $\leq 3$ in 4 of 6 of the CRB-15-treated mice after 14 days (Figure 2C). Similarly to the histological score, average levels of MPO activity were not different between IgG2a and CRB-15, whereas 4 of 6 CRB-15-treated mice had MPO activity $<20$ units/L and not different from $\mathrm{H}_{2} \mathrm{O}$ controls (Figure 2D). Finally, CRB-15 did not prevent the increase in gene expression level of IL-1 $\beta$ and IL-6 in the colon of DSS-exposed mice (Figure 2E and data not shown).

Next we examined the proportion of small intestinal $\alpha \beta T$ and $\gamma \delta \mathrm{T}$ cells, the latter accounting for $\leq 40 \%$ to $\leq 50 \%$ of intraepithelial lymphocytes IELs ${ }^{45}$ and exerting antiinflammatory properties in various mouse colitis models. ${ }^{46,47}$ DSS administration induced an increased proportion of $\gamma \delta \mathrm{T}$ cells, and respectively, decreased $\alpha \beta T$ cells at day 7 (Figure 2F). After 1 week and more than 2 weeks of treatment, CRB-15 further increased the proportion of $\gamma \delta \mathrm{T}$ cells $(77.1 \%$ versus $49.5 \%$ in $\operatorname{IgG} 2 \mathrm{a}$ ), and decreased $\alpha \beta \mathrm{T}$ cells, in DSSexposed mice compared to IgG2a (Figure $2 \mathrm{~F}$ ). Among $\gamma \delta \mathrm{T}$ cells, no treatment-related differences were noted in the various subpopulations (CD4, CD $8 \alpha \alpha, C D 8 \alpha \beta, C D 4, C D 8 \alpha \alpha$, and CD4 CD $8 \alpha \beta$; Supplemental Table S1). Immunohistochemistry of colon allowed confirmation that $\gamma \delta$ T cells were present in the colon of mice and seemed to be increased in DSS-CRB-15treated mice (Supplemental Figure S1).

In contrast to IELs, we found no significant effects of IL-15 blockade on T-cell populations in spleen and lymph nodes. Moreover, levels of pro-inflammatory cytokines, such as IL-2, IL-17, or IFN $\gamma$, and the anti-inflammatory cytokine IL-10 in blood were not significantly modulated in the presence versus absence of colitis (data not shown). These results suggested that in this model of chronic colitis, inflammation was not systemic.

\section{CRB-15 Delays Colitis-Associated Bone Loss}

Femoral BMD increased over the course of three weeks, in control $\left(\mathrm{H}_{2} \mathrm{O}\right)$ mice, whereas BMD remained stable or decreased in mice exposed to DSS (Figure 3A). However, CRB-15 initially attenuated BMD loss in these animals, to the point that in mice treated with CRB-15, femur BMD did not differ between DSS-CRB-15 and the control $\left(\mathrm{H}_{2} \mathrm{O}\right.$ IgG2a or $\left.\mathrm{H}_{2} \mathrm{O}-\mathrm{CRB}-15\right)$ groups at 14 days. At 21 days, however, femoral BMD was similar in CRB-15- and IgG2atreated mice from the DSS groups (Figure 3A) and significantly lower than in the control groups.

Trabecular microarchitecture was analyzed ex vivo in vertebra and distal femur at 14 and 21 days. A significant decrease in trabecular bone volume fraction and trabecular thickness occurred in DSS-IgG2a-treated mice compared to control mice at 14 days and 21 days after DSS administration. We noted that control mice had a low femur trabecular bone volume fraction at 21 days without which we can explain it and consequently no difference appeared between DSS-exposed mice and controls. CRB-15 prevented these alterations in bone microarchitecture at 14 days. However, 21 days after DSS administration, bone volume fraction and trabecular thickness were not significantly different in DSS mice treated with CRB-15 compared to IgG2a (Figure 3B). Lower cortical bone volume and cortical thickness were also observed in mice exposed to DSS for 21 days without significant difference between CRB-15 and IgG2a (Supplemental Table S2).

\section{CRB-15 Decreases 0steoclast Numbers}

To understand the mechanisms by which CRB-15 delayed bone loss in this model, we next analyzed its effects on bone
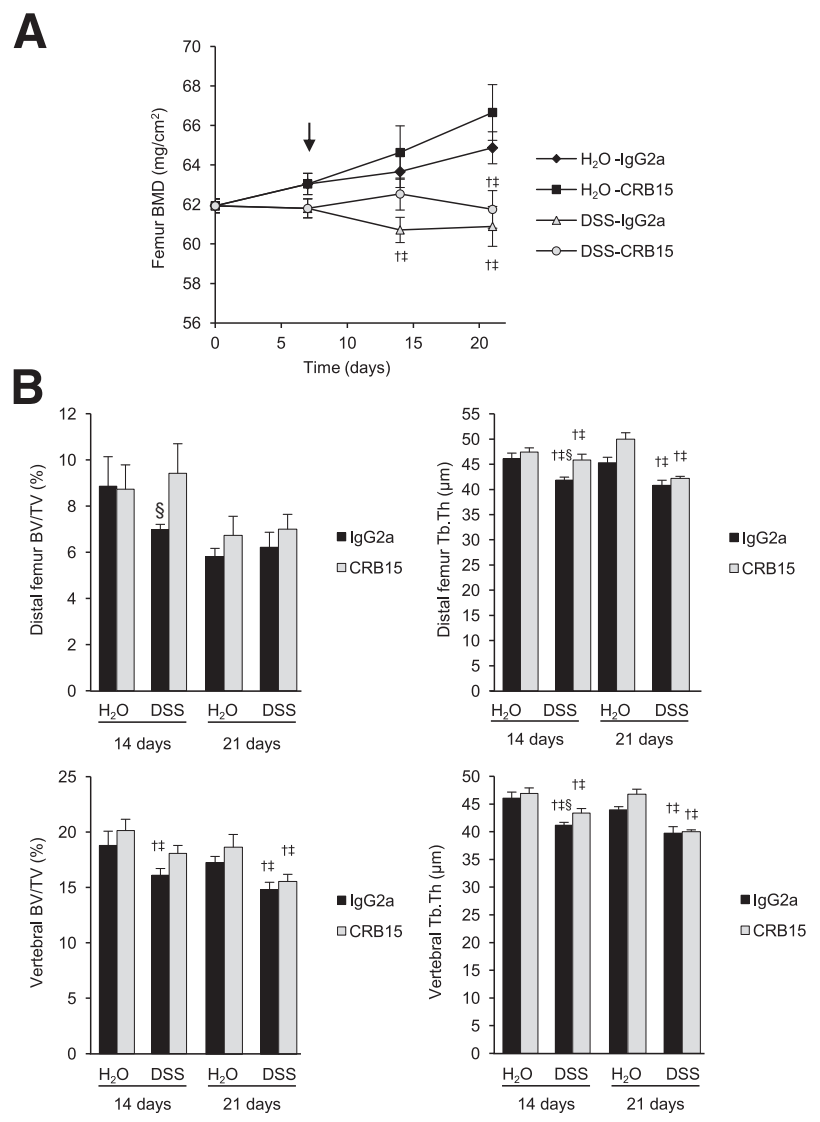

Figure $3 \mathrm{BMD}$ and bone microarchitecture in IgG2a- and CRB15-treated mice. A: BMD was measured at the femur at baseline, and at 7, 14, and 21 days after DSS administration. Values are the mean of three independent experiments ( $n=7$ to 27 mice per group). Arrow indicates the beginning of treatment. B: Distal femur and vertebral trabecular bone volume fraction and trabecular thickness were determined by microcomputed tomography 14 days and 21 days after DSS administration. Values are the means \pm SEM of three independent experiments ( $n=5$ to 18 mice per group). ${ }^{\dagger} P<0.05$ versus $\mathrm{H}_{2} 0$ IgG2a, ${ }^{\ddagger} P<0.05$ versus $\mathrm{H}_{2} 0$-CRB- 15 , and ${ }^{\S} P<0.05$ versus DSS CRB 15 . 
A

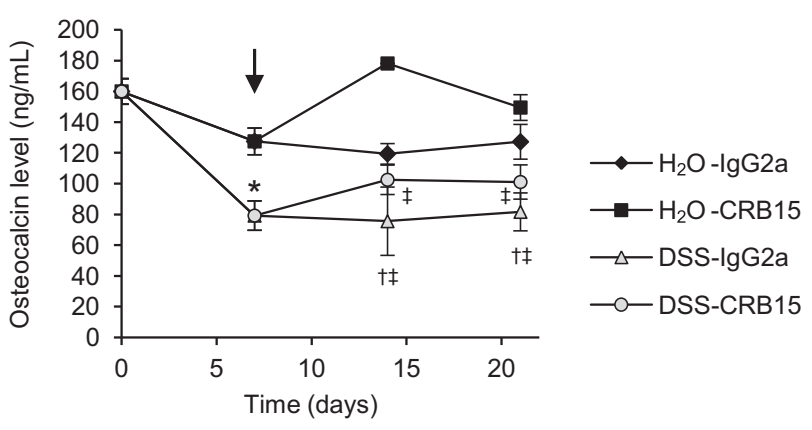

B

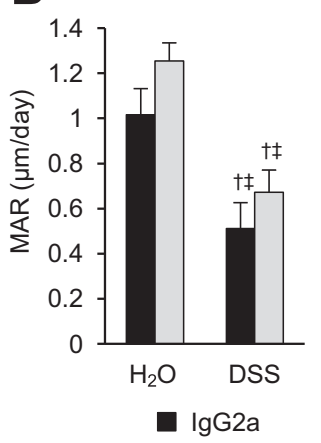

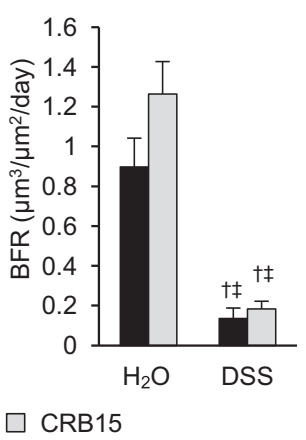

C

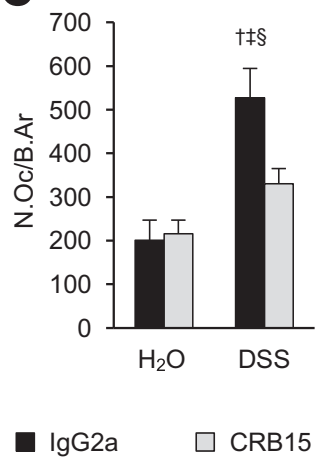

D

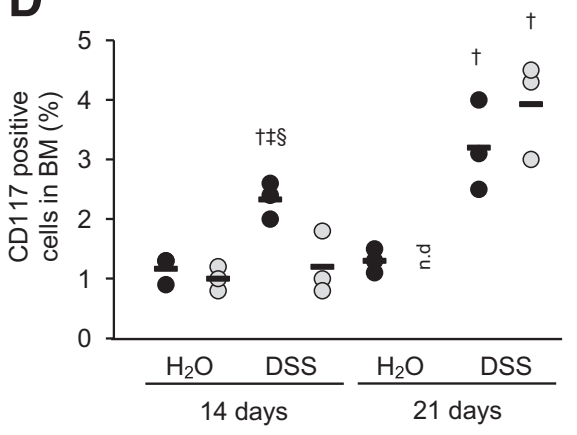

- $\lg \mathrm{g} 2 \mathrm{a}$

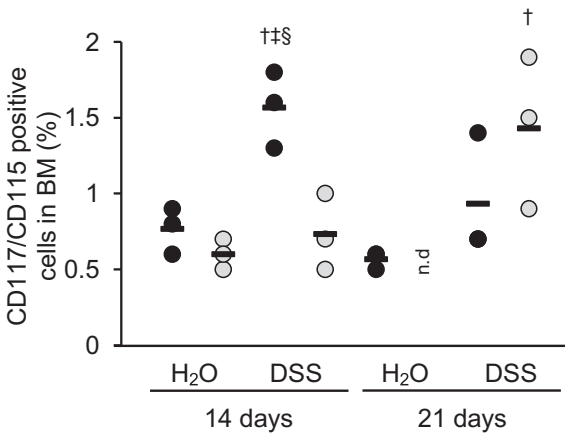

O CRB15

Figure 4 Indices of bone turnover in IgG2a- and CRB15-treated mice. A: Level of osteocalcin was measured in sera at baseline, and at 7, 14, and 21 days after DSS administration. Arrow indicates the beginning of treatment. B: Mineral apposition rate and bone formation rate were determined 21 days after DSS administration on bone surfaces at the femoral midshaft. C: Number of osteoclasts per bone area was measured 21 days after DSS administration on the secondary spongiosa of the proximal femur metaphysis. A-C: Values are means \pm SEM of two independent experiments ( $n=5$ to 12 mice per group). D: CD117- and CD117/CD115-positive cells were evaluated in bone marrow at 14 and 21 days after DSS administration. Black dot represents CD3 ${ }^{-}$CD45 ${ }^{-}$CD11 $b^{-}$ $\mathrm{CD}_{117^{+}}$cell population on the left panel, and $\mathrm{CD} 3^{-} \mathrm{CD} 45^{-} \mathrm{CD} 11 \mathrm{~b}^{-} \mathrm{CD} 117^{+} \mathrm{CD} 115^{+}$cells on the right panel. Each value was represented by a black dot and mean by a black line ( $n=3$ mice per group). Data were analyzed using a $2 \mathrm{~F}$-analysis of variance and post hoc testing was then performed using Fisher's Protected Least Significant Difference to compare IgG2a and CRB-15 in the DSS subgroup of mice. ${ }^{*} P<0.05$ versus $\mathrm{H}_{2} 0,{ }^{\dagger} P<0.05$ versus $\mathrm{H}_{2} 0$-IgG2a, ${ }^{\ddagger} P<$ 0.05 versus $\mathrm{H}_{2} 0$-CRB-15, and ${ }^{\S} P<0.05$ versus DSS-CRB- 15 .

turnover. Serum levels of osteocalcin were modestly but significantly decreased after 7 days of DSS administration, and remained lower in IgG2a-treated mice compared to controls $\left(\mathrm{H}_{2} \mathrm{O}\right)$ until 21 days (Figure 4A). Furthermore, dynamic histomorphometrical indices of bone formation (mineral apposition rate and bone formation rate), as evaluated at the end of the experiment, were decreased in mice exposed to DSS (Figure 4B). CRB-15 first induced a low but significant increase in osteocalcin levels in both DSS and $\mathrm{H}_{2} \mathrm{O}$ mice, which then remained stable. Hence, after 21 days, osteocalcin levels did not significantly differ between DSS mice treated with CRB-15 and mice without colitis $\left(\mathrm{H}_{2} \mathrm{O}-\mathrm{IgG} 2 \mathrm{a}\right)$ (Figure 4A). However, mineral apposition rate and bone formation rate were not significantly better after 2 weeks of CRB-15 treatment (Figure 4B).

Mice exposed to DSS had a markedly increased osteoclasts number, as evaluated at the end of the experiment (Figure 4C), and CD117 ${ }^{+}$and CD117/CD115 ${ }^{+}$osteoclast progenitors $^{44}$ in the bone marrow at 14 and 21 days (Figure 4D). The osteoclasts number was significantly attenuated after 2 weeks of CRB-15 treatment (Figure 4C). Moreover, CRB-15 delayed the increase in osteoclastogenic progenitors in the bone marrow until 21 days (Figure 4D). Compared to IgG2a, CRB-15 also prevented the increase in $\mathrm{CD} 44^{+}$leukocytes and in particular of CD11 $\mathrm{b}^{+}$monocytes/ macrophages in mice exposed to DSS (Table 2). These results suggested that in addition to its direct effects on osteoclasts, ${ }^{33}$ CRB-15 did prevent the recruitment and/or expansion of immune cells in the bone marrow.

CRB-15 Reverses the Pro-Inflammatory Cytokine Profile in the Bone Marrow

We next analyzed expression levels of genes implicated in bone formation and resorption, namely alkaline phosphatase (ALP), Collagen 1A1 (Col1A1), RANKL, and OPG, as well as pro- and anti-inflammatory cytokines, such as $\mathrm{TNF} \alpha$, IL-6, and IL-10 in the bone. In keeping with the decrease of serum osteocalcin (previously described), ALP and Col1A1 expression was profoundly inhibited in (DSS) colitis mice (Figure 5A). CRB-15 prevented the decrease of ALP and Col1A1 at 14 days, but not later (Figure 5A).

Tnf $\alpha$ gene expression more than doubled in DSS exposed mice, and CRB-15 tended to prevent this increase from 14 
Table 2 Analysis of Immune Cell Populations in Bone Marrow of IgG2a- and CRB15-Treated Mice

\begin{tabular}{|c|c|c|c|c|c|}
\hline \multirow[b]{2}{*}{ Immune cell subset (\%) } & \multirow[b]{2}{*}{ Days after DSS } & \multicolumn{2}{|l|}{$\mathrm{H}_{2} \mathrm{O}$} & \multicolumn{2}{|l|}{ DSS } \\
\hline & & $\mathrm{IgG} 2 \mathrm{a}$ & CRB-15 & IgG2a & CRB-15 \\
\hline CD44 & 14 days & $22.90 \pm 1.91$ & $12.04 \pm 0.60$ & $27.00 \pm 4.90^{*}$ & $20.29 \pm 5.78$ \\
\hline \multirow[t]{2}{*}{ CD4 } & 14 days & $1.85 \pm 0.51$ & $1.73 \pm 0.37$ & $1.75 \pm 0.140$ & $1.55 \pm 0.05$ \\
\hline & 21 days & $1.48 \pm 0.34$ & ND & $0.79 \pm 0.39$ & $0.75 \pm 0.29$ \\
\hline CD8 & 14 days & $3.65 \pm 1.29$ & $2.51 \pm 0.34$ & $3.82 \pm 0.26$ & $3.6 \pm 0.04$ \\
\hline NK1.1 & 21 days & $1.36 \pm 0.12$ & ND & $0.92 \pm 0.21$ & $1.25 \pm 0.28$ \\
\hline \multirow[t]{2}{*}{ CD11b } & 14 days & $23.14 \pm 1.13$ & $22.48 \pm 1.47$ & $41.59 \pm 1.44^{*^{\dagger}}$ & $30.78 \pm 8.78$ \\
\hline & 21 days & $10.12 \pm 1.69$ & ND & $40.09 \pm 5.11^{\dagger \S}$ & $23.96 \pm 1.47^{\dagger \ddagger}$ \\
\hline \multirow[t]{2}{*}{ CD117 } & 14 days & $1.17 \pm 0.13$ & $1.0 \pm 0.11$ & $2.33 \pm 0.18^{* \dagger \delta}$ & $1.2 \pm 0.31^{\ddagger}$ \\
\hline & 21 days & $1.30 \pm 0.11$ & ND & $3.2 \pm 0.44^{\dagger}$ & $3.93 \pm 0.47^{\dagger}$ \\
\hline
\end{tabular}

Values are the means \pm SEM of two independent experiments ( $n=3$ mice per group).

${ }^{*} P<0.05$ versus $\mathrm{H}_{2} 0$-CRB- 15 .

${ }^{\dagger} P<0.05$ versus H2O-IgG2a.

${ }^{\ddagger} P<0.05$ versus DSS-IgG2a.

${ }^{\S} P<0.05$ versus DSS-CRB- 15 .

ND, not determined.

days, but this effect only reached the significance at 21 days (Figure 5C), and $I l 6$ gene expression levels remained unchanged (Figure 5C). CRB-15 also enhanced the expression of the anti-inflammatory cytokine IL-10 in DSS mice at day 21 (Figure 5C). In contrast, both RANKL and OPG were reduced 14 days after DSS administration, and OPG remained low at 21 days compared to $\mathrm{H}_{2} \mathrm{O}$ controls, without significant CRB-15 effects (Figure 5B).

\section{Discussion}

A DSS mouse colitis model associated with bone loss has previously been described. ${ }^{48}$ Using this model and a selective inhibitor of IL-15, CRB- $15,{ }^{37}$ we have now delineated the role of this major $\mathrm{T}$ cell growth factor and inflammatory cytokine on the systemic and skeletal complications of colitis and characterized the mechanisms by which IL- 15 contributes to alter bone remodeling in IBD. Consistent with the profile of bone turnover markers in humans ${ }^{49-51}$ and other mouse colitis models, ${ }^{48,52,53}$ bone loss in DSS-treated mice was characterized by suppressed bone formation but an increased number of osteoclast progenitors $\left(\mathrm{CD} 117^{+}\right)$in the bone marrow and osteoclasts on bone surfaces. These alterations result from the dual effects of inflammatory cytokines that inhibit osteoblasts while activating osteoclastogenesis. ${ }^{12-18}$ Hence, the inhibition of Collal and ALP gene expression, as well as the increase of osteoclast numbers after DSS administration were paralleled by a marked stimulation of Tnf $\alpha$ gene expression in bone. This explains why treatment of IBD patients with infliximab, a TNF $\alpha$ inhibitor, is associated with some improvement of bone mineral density and an increase of bone ALP. ${ }^{54,55}$

Il-15 has been implicated in both colonic inflammation $^{25,26}$ and osteoclast activation. ${ }^{33}$ In turn, CRB-15 prevented the increase of $\mathrm{CD} 117^{+}$cells at day 14 and reduced osteoclast numbers at 21 days. These effects occurred without a significant improvement of the OPG/RANKL ratio, which was markedly lower at the end of the experiment, and may therefore be at least partly attributed to the inhibition of IL-15 itself. Indeed, IL-15 is able to enhance osteoclastogenesis both directly, by co-stimulating RANKL-induced differentiation and function in osteoclasts, and indirectly, by inducing proliferation and activation of $\mathrm{T}$ cells and their production of IFN $\gamma$ and RANKL. ${ }^{33}$ Moreover, CRB-15 decreased Tnfa and increased $I l 10$ gene expression after 21 days, which could contribute to the significant decrease of osteoclast numbers observed at the end of the experiment. Indeed, IL-10 deficient mice develop colitis with osteopenia, ${ }^{52}$ whereas IL-10 inhibits osteoclastogenesis. ${ }^{56}$ On another hand, CRB-15 did not influence $I L-6$ gene expression in bone, another pro-inflammatory cytokine implicated in IBD and known to inhibit bone formation ${ }^{16}$ while increasing bone resorption. ${ }^{57}$

Although CRB-15 significantly reduced Tnf $\alpha$ gene expression only by day 21 , it fully prevented the inhibition of ALP and Col1A1 expression and partially restored serum osteocalcin levels early on (day 14). It is noted that CRB-15 tended to increase osteocalcin levels and bone mineral density even in control mice (ie, in the absence of inflammation). Taken together with our previous observations of an increased bone mass in $I L-15 R \alpha^{-1-}$ mice ${ }^{33}$, these results 
A

B
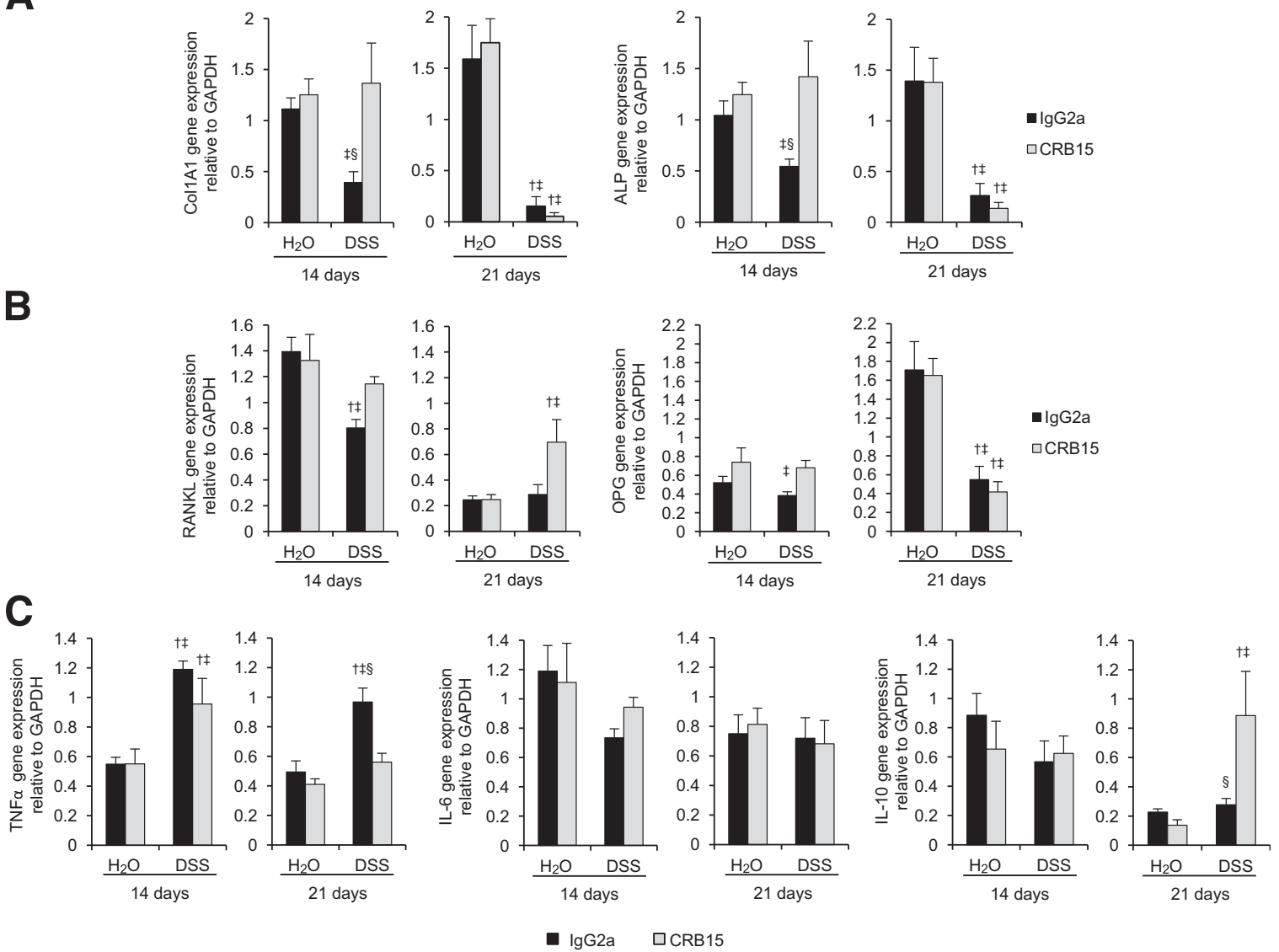

Figure 5 Gene expression in bone of IgG2a- and CRB15-treated mice. In each experiment, mRNA extraction was performed on the femur at 14 or 21 days after DSS administration. Gene expression was determined as a ratio of mRNA to the housekeeping gene glyceraldehyde-3-phosphate dehydrogenase. A: Expression of mRNA for Col1A1 and ALP genes. B: Expression of mRNA for receptor activator of NF- $\kappa B$ ligand (RANKL) and OPG genes. C: Expression of mRNA for IL-6, TNF $\alpha$, and $I L-10$ genes. Values are means \pm SEM ( $n=4$ mice per group). ${ }^{\dagger} P<0.05$ versus $\mathrm{H}_{2} 0$-IgG2a, ${ }^{\ddagger} P<0.05$ versus $\mathrm{H}_{2} 0$-CRB-15, and ${ }^{\S} P<0.05$ versus DSS-CRB-15.

suggest that IL-15 could further inhibit bone formation independently of TNF $\alpha$. As a result, CRB-15 initially restored femur BMD gain and delayed the alterations of trabecular microarchitecture associated with colitis. However, these protective effects were not maintained over the entire length of the experiment. Hence, we propose that IL-15 and TNF $\alpha$ could both be implicated in bone loss in the early stages of IBD, whereas decreased OPG expression may become the predominant mechanism of bone loss over time. This hypothesis is further supported by prior evidence showing that recombinant OPG inhibits bone resorption and restores bone mass in the adoptive transfer mouse colitis model, however, without improving bone formation. ${ }^{58}$ Similarly, exogenous recombinant OPG reverses bone alterations in IL-2 deficient mice. Moreover, in this model, OPG exerts beneficial effect on the development of colitis and inflammation by decreasing dendritic cells. ${ }^{53}$

In colitis mice, the number of leukocytes and in particular, CD11b positive cells in the bone marrow were two to four times higher than controls. In contrast, the various T-cell populations in the bone marrow, lymph nodes, and spleen apparently remained unaffected. Thus, monocytes/ macrophages seem to be the predominant vector of inflammation within the bone marrow secondary to DSSinduced colitis. Inflammatory cell infiltrates associated with elevated level of TNF $\alpha$ have been previously reported in bone marrow of mice that develop colitis after transfer of $\mathrm{CD} 4{ }^{+} \mathrm{CD} 45 \mathrm{RB}^{\mathrm{Hi}} \mathrm{T}$ cells, although the subpopulations of inflammatory cells were not specifically evaluated in that study ${ }^{58}$ An increased number of inflammatory cells, CD11b positive monocytes, and CD4 positive $\mathrm{T}$ cells has also been observed in the bone marrow of arthritic rats. ${ }^{59}$ Monocytes and macrophages are major sources of IL-15, which in turn exerts an autocrine activity on macrophages, stimulating their production of $\mathrm{TNF}^{2}{ }^{24}$ Hence, elevated TNF $\alpha$ expression in the bone marrow of colitis mice could be the result of infiltrating macrophages responding to IL-15, and likely additional stimuli. This could explain how CRB-15 was capable to prevent the recruitment and/or expansion of $\mathrm{CD} 11 \mathrm{~b}^{+}$cells in the bone marrow and to eventually decrease $\mathrm{TNF} \alpha$, thereby limiting a $\mathrm{TNF} \alpha$-mediated inflammatory loop in the bone microenvironment.

DSS administration induced early weight loss and a marked increase in DAI and mortality. Nevertheless, in 
conditions of chronic colitis (1\% DSS), body weight partly recovered and the DAI eventually stabilized in IgG2a-treated mice. Inhibition of IL-15 prompted weight recovery, quickly decreased DAI, and ultimately improved survival. By the end of the experiment, however, the beneficial effects of CRB-15 on the systemic manifestations of the disease were no more apparent. This could be due to a survivors effects (ie, survival of only less severely affected control mice at the end of the experiment) but could also be explained by a progressive loss of function of IL-15, and/or its inhibitor, during the phase of chronic inflammation (although IL-15 receptor remained expressed in colon 21 days after DSS administration, data not shown). Moreover, and as previously described, ${ }^{60}$ the effects of CRB-15 on the clinical manifestations of colitis did not necessarily reflect the severity of inflammation and mucosal destruction in the colon, which on average did not significantly differ between DSS-IgG2a and DSS-CRB-15-treated mice. Nevertheless, the effects of CRB-15 on colon damage and inflammation appeared to be heterogeneous, with approximately $50 \%$ of mice showing a marked reduction of inflammatory markers (such as MPO activity), whereas the other half did not. These observations might be explained by the dual role of IL-15 on intestinal inflammation. On the one hand, IL-15 is highly expressed in the inflamed mucosa of IBD patients and stimulates proliferation and activation of $\mathrm{T}$ cells and their production of inflammatory cytokines such as TNF $\alpha$ and IFN $\gamma .{ }^{61}$ Hence, IL-15 deficient mice are less sensitive to both acute and chronic colitis after DSS administration. ${ }^{31}$ On the other hand, it has been shown that IL-15 protects intestinal epithelial cells from apoptosis and consequently, neutralization of IL-15 could aggravate epithelial damage, cell death, and the severity of the disease. ${ }^{62}$ In our model, no modifications of peripheral subpopulations of T cells and cytokines levels in blood were observed after DSS administration or CRB-15 treatment. In contrast, CRB-15 enhanced the proportion of $\gamma \delta \mathrm{T}$ cells in the small intestinal epithelium. Previous reports indicate that large numbers of $\gamma \delta \mathrm{T}$ cells are present in the intestinal epithelium after DSS administration to improve tissue repair, whereas $\gamma \delta \mathrm{T}$ cells deficient mice are more sensitive to mucosal damage induced by DSS. ${ }^{63}$ Although $\gamma \delta \mathrm{T}$ cells were also present in the colon epithelium, conclusions from our work are limited by the absence of analysis of T-cell subpopulations directly in the colon.

In conclusion, these results highlight the functions of IL-15 on the inhibition of bone formation and stimulation of osteoclastogenesis in IBD. In turn, they provide evidence that IL-15 blockade by CRB-15 delays bone loss, whereas improves the clinical manifestations and survival on DSSinduced chronic colitis. However, the systemic and skeletal benefits of CRB-15 were limited and did not entirely correlate with its effects on colon inflammation and damage, which were heterogeneous. These observations confirm and extend the role of IL-15 on bone remodeling and may support the development of IL-15 antagonists for treatment in IBD.

\section{Acknowledgments}

We thank the excellent technical work of Juliette Cicchini, Madeleine Lachize, Casimir de Rham, Joël Pimenta, Delphine Mouron, and Catherine Pythoud.

\section{Supplemental Data}

Supplemental material for this article can be found at http://dx.doi.org/10.1016/j.ajpath.2013.02.033.

\section{References}

1. Shih DQ, Targan SR: Immunopathogenesis of inflammatory bowel disease. World J Gastroenterol 2008, 14:390-400

2. Bernstein CN, Blanchard JF, Leslie W, Wajda A, Yu BN: The incidence of fracture among patients with inflammatory bowel disease. A population-based cohort study. Ann Intern Med 2000, 133:795-799

3. Dubner SE, Shults J, Baldassano RN, Zemel BS, Thayu M, Burnham JM, Herskovitz RM, Howard KM, Leonard MB: Longitudinal assessment of bone density and structure in an incident cohort of children with Crohn's disease. Gastroenterology 2009, 136:123-130

4. Sylvester FA: IBD and skeletal health: children are not small adults! Inflamm Bowel Dis 2005, 11:1020-1023

5. Bernstein CN, Leslie WD: The pathophysiology of bone disease in gastrointestinal disease. Eur J Gastroenterol Hepatol 2003, 15: 857-864

6. Kuhn R, Lohler J, Rennick D, Rajewsky K, Muller W: Interleukin10-deficient mice develop chronic enterocolitis. Cell 1993, 75: 263-274

7. Sadlack B, Merz H, Schorle H, Schimpl A, Feller AC, Horak I: Ulcerative colitis-like disease in mice with a disrupted interleukin-2 gene. Cell 1993, 75:253-261

8. Powrie F, Leach MW, Mauze S, Caddle LB, Coffman RL: Phenotypically distinct subsets of CD4 $+\mathrm{T}$ cells induce or protect from chronic intestinal inflammation in C. B-17 scid mice. Int Immunol 1993, 5:1461-1471

9. Dieleman LA, Ridwan BU, Tennyson GS, Beagley KW, Bucy RP, Elson CO: Dextran sulfate sodium-induced colitis occurs in severe combined immunodeficient mice. Gastroenterology 1994, 107 : $1643-1652$

10. Kabashima K, Saji T, Murata T, Nagamachi M, Matsuoka T, Segi E, Tsuboi K, Sugimoto Y, Kobayashi T, Miyachi Y, Ichikawa A, Narumiya S: The prostaglandin receptor EP4 suppresses colitis, mucosal damage and CD4 cell activation in the gut. J Clin Invest 2002, 109:883-893

11. Harris L, Senagore P, Young VB, McCabe LR: Inflammatory bowel disease causes reversible suppression of osteoblast and chondrocyte function in mice. Am J Physiol Gastrointest Liver Physiol 2009, 296: G1020-G1029

12. Gilbert L, He X, Farmer P, Boden S, Kozlowski M, Rubin J, Nanes MS: Inhibition of osteoblast differentiation by tumor necrosis factor-alpha. Endocrinology 2000, 141:3956-3964

13. Bertolini DR, Nedwin GE, Bringman TS, Smith DD, Mundy GR: Stimulation of bone resorption and inhibition of bone formation in vitro by human tumour necrosis factors. Nature 1986, 319: 516-518

14. Azuma Y, Kaji K, Katogi R, Takeshita S, Kudo A: Tumor necrosis factor-alpha induces differentiation of and bone resorption by osteoclasts. J Biol Chem 2000, 275:4858-4864

15. Dewhirst FE, Stashenko PP, Mole JE, Tsurumachi T: Purification and partial sequence of human osteoclast-activating factor: identity with interleukin 1 beta. J Immunol 1985, 135:2562-2568 
16. Sylvester FA, Wyzga N, Hyams JS, Gronowicz GA: Effect of Crohn's disease on bone metabolism in vitro: a role for interleukin-6. J Bone Miner Res 2002, 17:695-702

17. Palmqvist $\mathrm{P}$, Persson E, Conaway HH, Lerner UH: IL-6, leukemia inhibitory factor, and oncostatin $\mathrm{M}$ stimulate bone resorption and regulate the expression of receptor activator of NF-kappa B ligand, osteoprotegerin, and receptor activator of NF-kappa B in mouse calvariae. J Immunol 2002, 169:3353-3362

18. Gao Y, Grassi F, Ryan MR, Terauchi M, Page K, Yang X, Weitzmann MN, Pacifici R: IFN-gamma stimulates osteoclast formation and bone loss in vivo via antigen-driven $\mathrm{T}$ cell activation. $\mathrm{J}$ Clin Invest 2007, 117:122-132

19. Lacey DL, Timms E, Tan HL, Kelley MJ, Dunstan CR, Burgess T, Elliott R, Colombero A, Elliott G, Scully S, Hsu H, Sullivan J, Hawkins N, Davy E, Capparelli C, Eli A, Qian YX, Kaufman S, Sarosi I, Shalhoub V, Senaldi G, Guo J, Delaney J, Boyle WJ: Osteoprotegerin ligand is a cytokine that regulates osteoclast differentiation and activation. Cell 1998, 93:165-176

20. Moschen AR, Kaser A, Enrich B, Ludwiczek O, Gabriel M, Obrist P, Wolf AM, Tilg H: The RANKL/OPG system is activated in inflammatory bowel disease and relates to the state of bone loss. Gut 2005, 54:479-487

21. Romas E, Sims NA, Hards DK, Lindsay M, Quinn JW, Ryan PF, Dunstan CR, Martin TJ, Gillespie MT: Osteoprotegerin reduces osteoclast numbers and prevents bone erosion in collagen-induced arthritis. Am J Pathol 2002, 161:1419-1427

22. Grabstein KH, Eisenman J, Shanebeck K, Rauch C, Srinivasan S, Fung V, Beers C, Richardson J, Schoenborn MA, Ahdieh M, Johnson L, Alderson MR, Watson JD, Anderson DM, Giri JG: Cloning of a $\mathrm{T}$ cell growth factor that interacts with the beta chain of the interleukin-2 receptor. Science 1994, 264:965-968

23. Bamford RN, Battiata AP, Burton JD, Sharma H, Waldmann TA: Interleukin (IL) $15 / \mathrm{IL}-\mathrm{T}$ production by the adult T-cell leukemia cell line HuT-102 is associated with a human T-cell lymphotrophic virus type I region /IL-15 fusion message that lacks many upstream AUGs that normally attenuates IL-15 mRNA translation. Proc Natl Acad Sci USA 1996, 93:2897-2902

24. Alleva DG, Kaser SB, Monroy MA, Fenton MJ, Beller DI: IL-15 functions as a potent autocrine regulator of macrophage proinflammatory cytokine production: evidence for differential receptor subunit utilization associated with stimulation or inhibition. J Immunol 1997, 159:2941-2951

25. Nishiwaki T, Ina K, Goto H, Watanabe O, Tsuzuki T, Furuta R, Ando T, Hibi K, Kusugami K: Possible involvement of the interleukin-15 and interleukin-15 receptor system in a heightened state of lamina propria B cell activation and differentiation in patients with inflammatory bowel disease. J Gastroenterol 2005, 40:128-136

26. Vainer B, Nielsen $\mathrm{OH}$, Hendel J, Horn T, Kirman I: Colonic expression and synthesis of interleukin 13 and interleukin 15 in inflammatory bowel disease. Cytokine 2000, 12:1531-1536

27. Kennedy MK, Glaccum M, Brown SN, Butz EA, Viney JL, Embers M, Matsuki N, Charrier K, Sedger L, Willis CR, Brasel K, Morrissey PJ, Stocking K, Schuh JC, Joyce S, Peschon JJ: Reversible defects in natural killer and memory CD8 T cell lineages in interleukin 15-deficient mice. J Exp Med 2000, 191:771-780

28. Chae DW, Nosaka Y, Strom TB, Maslinski W: Distribution of IL-15 receptor alpha-chains on human peripheral blood mononuclear cells and effect of immunosuppressive drugs on receptor expression. J Immunol 1996, 157:2813-2819

29. Kinoshita N, Hiroi T, Ohta N, Fukuyama S, Park EJ, Kiyono H: Autocrine IL-15 mediates intestinal epithelial cell death via the activation of neighboring intraepithelial NK cells. J Immunol 2002, 169:6187-6192

30. Ohta N, Hiroi T, Kweon MN, Kinoshita N, Jang MH, Mashimo T, Miyazaki J, Kiyono H: IL-15-dependent activation-induced cell death-resistant Th1 type CD8 alpha beta+NK1.1+ T cells for the development of small intestinal inflammation. J Immunol 2002, 169: 460-468
31. Yoshihara K, Yajima T, Kubo C, Yoshikai Y: Role of interleukin 15 in colitis induced by dextran sulphate sodium in mice. Gut 2006, 55 : 334-341

32. Ogata Y, Kukita A, Kukita T, Komine M, Miyahara A, Miyazaki S, Kohashi O: A novel role of IL-15 in the development of osteoclasts: inability to replace its activity with IL-2. J Immunol 1999, 162:2754-2760

33. Djaafar S, Pierroz DD, Chicheportiche R, Zheng XX, Ferrari SL, Ferrari-Lacraz $S$ : Inhibition of $T$ cell-dependent and RANKLdependent osteoclastogenic processes associated with high levels of bone mass in interleukin-15 receptordeficient mice. Arthritis Rheum 2010, 62:3300-3310

34. Ferrari-Lacraz S, Zheng XX, Kim YS, Li Y, Maslinski W, Li XC, Strom TB: An antagonist IL-15/Fc protein prevents costimulation blockade-resistant rejection. J Immunol 2001, 167:3478-3485

35. Ferrari-Lacraz S, Zanelli E, Neuberg M, Donskoy E, Kim YS, Zheng XX, Hancock WW, Maslinski W, Li XC, Strom TB, Moll T: Targeting IL-15 receptor-bearing cells with an antagonist mutant IL$15 / \mathrm{Fc}$ protein prevents disease development and progression in murine collagen-induced arthritis. J Immunol 2004, 173:5818-5826

36. McInnes IB, Liew FY: Interleukin 15: a proinflammatory role in rheumatoid arthritis synovitis. Immunol Today 1998, 19:75-79

37. Kim YS, Maslinski W, Zheng XX, Stevens AC, Li XC, Tesch GH, Kelley VR, Strom TB: Targeting the IL-15 receptor with an antagonist IL-15 mutant/Fc gamma2a protein blocks delayed-type hypersensitivity. J Immunol 1998, 160:5742-5748

38. Bouxsein ML, Pierroz DD, Glatt V, Goddard DS, Cavat F, Rizzoli R, Ferrari SL: beta-Arrestin2 regulates the differential response of cortical and trabecular bone to intermittent PTH in female mice. J Bone Miner Res 2005, 20:635-643

39. Parfitt AM, Drezner MK, Glorieux FH, Kanis JA, Malluche H, Meunier PJ, Ott SM, Recker RR: Bone histomorphometry: standardization of nomenclature, symbols, and units. Report of the ASBMR Histomorphometry Nomenclature Committee. J Bone Miner Res 1987, 2:595-610

40. Hartmann G, Bidlingmaier C, Siegmund B, Albrich S, Schulze J, Tschoep K, Eigler A, Lehr HA, Endres S: Specific type IV phosphodiesterase inhibitor rolipram mitigates experimental colitis in mice. J Pharmacol Exp Ther 2000, 292:22-30

41. Velin D, Favre L, Bernasconi E, Bachmann D, Pythoud C, Saiji E, Bouzourene H, Michetti P: Interleukin-17 is a critical mediator of vaccine-induced reduction of Helicobacter infection in the mouse model. Gastroenterology 2009, 136:2237-2246

42. Velin D, Bachmann D, Bouzourene H, Michetti P: Mast cells are critical mediators of vaccine-induced Helicobacter clearance in the mouse model. Gastroenterology 2005, 129:142-155

43. Lefrancois L: Phenotypic complexity of intraepithelial lymphocytes of the small intestine. J Immunol 1991, 147:1746-1751

44. Jacquin C, Gran DE, Lee SK, Lorenzo JA, Aguila HL: Identification of multiple osteoclast precursor populations in murine bone marrow. J Bone Miner Res 2006, 21:67-77

45. Kagnoff MF: Current concepts in mucosal immunity. III Ontogeny and function of gamma delta $\mathrm{T}$ cells in the intestine. Am J Physiol 1998, 274:G455-G458

46. Kuhl AA, Pawlowski NN, Grollich K, Loddenkemper C, Zeitz M, Hoffmann JC: Aggravation of intestinal inflammation by depletion/deficiency of gammadelta $\mathrm{T}$ cells in different types of IBD animal models. J Leukoc Biol 2007, 81:168-175

47. Inagaki-Ohara K, Chinen T, Matsuzaki G, Sasaki A, Sakamoto Y, Hiromatsu K, Nakamura-Uchiyama F, Nawa Y, Yoshimura A: Mucosal T cells bearing TCRgammadelta play a protective role in intestinal inflammation. J Immunol 2004, 173:1390-1398

48. Hamdani G, Gabet Y, Rachmilewitz D, Karmeli F, Bab I, DresnerPollak R: Dextran sodium sulfate-induced colitis causes rapid bone loss in mice. Bone 2008, 43:945-950

49. Bjarnason I, Macpherson A, Mackintosh C, Buxton-Thomas M, Forgacs I, Moniz C: Reduced bone density in patients with inflammatory bowel disease. Gut 1997, 40:228-233 
50. Robinson RJ, Iqbal SJ, Abrams K, Al-Azzawi F, Mayberry JF: Increased bone resorption in patients with Crohn's disease. Aliment Pharmacol Ther 1998, 12:699-705

51. Croucher PI, Vedi S, Motley RJ, Garrahan NJ, Stanton MR, Compston JE: Reduced bone formation in patients with osteoporosis associated with inflammatory bowel disease. Osteoporos Int 1993, 3: 236-241

52. Dresner-Pollak R, Gelb N, Rachmilewitz D, Karmeli F, Weinreb M: Interleukin 10-deficient mice develop osteopenia, decreased bone formation, and mechanical fragility of long bones. Gastroenterology 2004, 127:792-801

53. Ashcroft AJ, Cruickshank SM, Croucher PI, Perry MJ, Rollinson S, Lippitt JM, Child JA, Dunstan C, Felsburg PJ, Morgan GJ, Carding SR: Colonic dendritic cells, intestinal inflammation, and $\mathrm{T}$ cell-mediated bone destruction are modulated by recombinant osteoprotegerin. Immunity 2003, 19:849-861

54. Bernstein M, Irwin S, Greenberg GR: Maintenance infliximab treatment is associated with improved bone mineral density in Crohn's disease. Am J Gastroenterol 2005, 100:2031-2035

55. Abreu MT, Geller JL, Vasiliauskas EA, Kam LY, Vora P, Martyak LA, Yang H, Hu B, Lin YC, Keenan G, Price J, Landers CJ, Adams JS, Targan SR: Treatment with infliximab is associated with increased markers of bone formation in patients with Crohn's disease. J Clin Gastroenterol 2006, 40:55-63

56. Evans KE, Fox SW: Interleukin-10 inhibits osteoclastogenesis by reducing NFATc1 expression and preventing its translocation to the nucleus. BMC Cell Biol 2007, 8:4

57. De Benedetti F, Rucci N, Del Fattore A, Peruzzi B, Paro R, Longo M, Vivarelli M, Muratori F, Berni S, Ballanti P, Ferrari S, Teti A:
Impaired skeletal development in interleukin-6-transgenic mice: a model for the impact of chronic inflammation on the growing skeletal system. Arthritis Rheum 2006, 54:3551-3563

58. Byrne FR, Morony S, Warmington K, Geng Z, Brown HL, Flores SA, Fiorino M, Yin SL, Hill D, Porkess V, Duryea D, Pretorius JK, Adamu S, Manoukian R, Danilenko DM, Sarosi I, Lacey DL, Kostenuik PJ, Senaldi G: CD4+CD45RBHi T cell transfer induced colitis in mice is accompanied by osteopenia which is treatable with recombinant human osteoprotegerin. Gut 2005, 54: $78-86$

59. Bogoch ER, Lee TC, Fornasier VL, Berger SA: Articular damage is associated with intraosseous inflammation in the subchondral bone marrow of joints affected by experimental inflammatory arthritis and is modified by zoledronate treatment. $\mathrm{J}$ Rheumatol 2007, 34: $1229-1240$

60. Perse M, Cerar A: Dextran sodium sulphate colitis mouse model: traps and tricks. Journal of biomedicine \& biotechnology 2012, 2012 718617

61. Liu Z, Geboes K, Colpaert S, D'Haens GR, Rutgeerts P, Ceuppens JL: IL-15 is highly expressed in inflammatory bowel disease and regulates local $\mathrm{T}$ cell-dependent cytokine production. J Immunol 2000, 164:3608-3615

62. Obermeier F, Hausmann M, Kellermeier S, Kiessling S, Strauch UG, Duitman E, Bulfone-Paus S, Herfarth H, Bock J, Dunger N, Stoeck M, Scholmerich J, Falk W, Rogler G: IL-15 protects intestinal epithelial cells. Eur J Immunol 2006, 36:2691-2699

63. Chen Y, Chou K, Fuchs E, Havran WL, Boismenu R: Protection of the intestinal mucosa by intraepithelial gamma delta T cells. Proc Natl Acad Sci USA 2002, 99:14338-14343 